EDITOR'S

\title{
Do statins improve outcomes and delay the progression of non-rheumatic calcific aortic stenosis?
}

\author{
Alessandro Parolari, ${ }^{1}$ Elena Tremoli, ${ }^{1,2}$ Laura Cavallotti, ${ }^{1}$ Matteo Trezzi, ${ }^{1}$ \\ Samer Kassem, ${ }^{1}$ Claudia Loardi, ${ }^{1}$ Fabrizio Veglia, ${ }^{1}$ Giovanni Ferrari, ${ }^{3}$ Davide Pacini, ${ }^{4}$ \\ Francesco Alamanni ${ }^{1}$
}

\begin{abstract}
- Additional data and figures are published online only. To view these files please visit the journal online (http://heart.bmj. com)

${ }^{1}$ Unit for Clinical Research in Atherothrombosis, Centro Cardiologico Monzino IRCCS; Department of Cardiovascular Sciences, University of Milan, Milan, ITALY

${ }^{2}$ Department of Pharmacological Sciences, University of Milan, Milan, ITALY

${ }^{3}$ Department of Surgery, Division of Cardiovascular Surgery, University of Pennsylvania School of Medicine, Philadelphia, PA ${ }^{4}$ Department of Cardiac Surgery, S Orsola-Malpighi Hospital, University of Bologna, Bologna, ITALY
\end{abstract}

\section{Correspondence to}

Dr Alessandro Parolari, Centro Cardiologico Monzino IRCCS, Via Parea 4, 20138 Milano, Italy; alessandro.parolari@ cardiologicomonzino.it

Accepted 7 December 2010 Published Online First 26 January 2011

\section{ABSTRACT}

Context It is not known whether statin treatment improves clinical outcomes and reduces aortic stenosis progression in non-rheumatic calcific aortic stenosis.

Objective A meta-analysis of studies was performed comparing statin therapy with placebo or no treatment on outcomes and on aortic stenosis progression echocardiographic parameters.

Data sources The authors searched Medline and Pubmed up to January 2010.

Data extraction Two independent reviewers independently abstracted information on study design (prospective vs retrospective or randomised vs nonrandomised), study and participant characteristics. Fixed and random effects models were used. A-priori subanalyses assessed the effect of statins on low-quality (retrospective or non-randomised) and on high-quality (prospective or randomised) studies separately.

Results Meta-analysis identified 10 studies with a total of 3822 participants (2214 non-statin-treated and 1608 statin-treated); five studies were classified as prospective and five as retrospective; concerning randomisation, three trials were randomised whereas seven were not. No significant differences were found in all-cause mortality, cardiovascular mortality or in the need for aortic valve surgery. Lower-quality (retrospective or non-randomised) studies showed that, in statin-treated patients, the annual increase in peak aortic jet velocity and the annual decrease in aortic valve area were lower, but this was not confirmed by the analysis in high-quality (prospective or randomised) studies. Statins did not significantly affect the progression over time of peak and mean aortic gradient. Conclusions Currently available data do not support the use of statins to improve outcomes and to reduce disease progression in non-rheumatic calcific aortic valve stenosis.

Non-rheumatic calcific aortic stenosis is the commonest valve disease in adults and the third most common cardiovascular diagnosis (after hypertension and the need for coronary bypass surgery). ${ }^{1}$ Surgery remains the only treatment option in advanced stages. ${ }^{1}$ As several studies have indicated that aortic stenosis progression is due to an active process sharing several features with atherosclerosis, several trials have assessed the role of statins in delaying such progression, but with conflicting results. ${ }^{2} 3$ Since 2001 , several studies, mainly observational, suggested that statin therapy delays the progression of calcific non-rheumatic aortic stenosis, assessed by echocardiography or CT.
These findings were not confirmed by three recent prospective randomised trials. ${ }^{4-6}$ For this reason, the role of statins in these patients is an open question. We have undertaken a meta-analysis of studies of the effect of statins on the incidence of hard endpoints and on retarding stenosis progression.

\section{METHODS}

The meta-analysis used PRISMA, ${ }^{7}$ and MOOSE guidelines. ${ }^{8}$ We performed a computerised literature search of Medline and PubMed up to January 2010, supplemented with manual bibliography reviews. The following free text search string (formatted for PubMed) was used: [(statins OR Hydroxymethylglutaryl coenzyme-a reductase inhibitors) AND aortic]. We used tangential electronic exploration of related articles and manual searches of bibliographies, related journals and reference lists of reviews. All peer-reviewed studies published reporting the effect of statin therapy on outcomes and on valve stenosis progression in patients with calcific non-rheumatic aortic stenosis were identified. The ability of the search strategy to identify four relevant studies was tested and found fit for purpose. All titles and abstracts of the identified articles were examined by two investigators (AP, DP) for potential eligibility for subsequent analysis.

The first step of the analysis was to collect all the trials conforming to the following criteria: (1) Studies comparing the mid or long-term effects ( $\geq 1$ year) of statin therapy versus placebo or no statins in patients affected by calcific non-rheumatic aortic stenosis; (2) Data concerning mid or long-term hard outcomes or about the progression of aortic stenosis had to be reported in the study.

The following hard endpoints were collected: death from any cause at follow-up (n/y); death from cardiovascular causes at follow-up (n/y); the need to undergo aortic valve surgery at follow-up (n/y).

Concerning aortic valve stenosis progression, the following variables were searched: peak aortic jet velocity progression (m/s per year); aortic valve area decrease ( $\mathrm{cm}^{2} /$ year); peak aortic gradient progression ( $\mathrm{mm} \mathrm{Hg}$ /year); mean aortic gradient progression (mm Hg/year).

The outcome definitions used by the original researchers were accepted. Bibliographies of included articles were also searched.

Several strategies were employed to avoid duplication of data. If the same institution had produced several studies, only those reporting recruitment times were considered. If there was sample overlap 
between studies, only the largest study was included. Data were abstracted and analysed by two authors (AP, MT), and disagreements were resolved by consensus.

\section{Analyses}

Data were analysed by means of RevMan 5 (RevMan 5.0.22; Cochrane Collaboration, Oxford, UK) and Comprehensive Meta-analysis version 2 (Biostat, Englewood, New Jersey, USA). Effects on dichotomous outcomes were expressed as OR with $95 \%$ CI. Effects on continuous variables were expressed as mean difference with $95 \%$ CI.

Heterogeneity was assessed using the $\chi^{2}$ test; in addition, the $\mathrm{I}^{2}$ was calculated to quantify the degree of heterogeneity across trials that could not be attributable to chance alone. $\mathrm{I}^{2}$, the proportion of variability not attributable to chance alone, provides an improved measure of heterogeneity between trials and is not limited by power. ${ }^{9}$ When there was no significant heterogeneity, treatment effects were pooled with the fixedeffects model, but if there was significant $(p \leq 0.1)$ heterogeneity in the main analysis or in a subanalysis, the random-effects model was used; when a random-effects analysis was performed, among-study variance was also assessed with the $\tau^{2}$ statistic.

Subanalyses, defined a priori, were the analyses of prospective and retrospective studies, and of randomised and non-randomised studies performed separately. In addition, the effect of statin treatment on aortic stenosis progression parameters was assessed in studies that enrolled patients with average lowdensity lipoprotein cholesterol levels of $130 \mathrm{mg} / \mathrm{dl}$ or less.
Finally, weighted fixed-effects meta-regression was used to examine the possibility of effect modification on aortic stenosis progression by the duration of statin treatment.

Sensitivity of the meta-analyses was assessed after removal of studies in which the largest (or smallest) effect was found and of the study with the largest number of patients. In addition, we performed random-effects meta-analysis on the outcomes of interest.

Publication bias was explored through visual inspection of funnel plots, and by one-tailed Egger's test. Other than for the $\mathrm{Q}$ statistic, statistical significance was defined by $\mathrm{p} \leq 0.05$.

\section{RESULTS}

\section{Selected studies}

The selection criteria described under the Methods section were applied to 812 studies identified by the literature searches; the publications were examined, and 21 candidate trials were identified for further assessment (see supplementary data for bibliography, available online only). Of these, six were discarded as they were not focused on therapy with statins. On further examination of the 15 remaining studies, five were excluded either because they did not report any extractable data, because of possible duplicate publication, or because they were focused on rheumatic aortic stenosis. Of the 10 studies finally selected for meta-analysis (table 1), five were prospective and five were retrospective, whereas three were randomised and seven were not randomised, respectively. One of the retrospective, nonrandomised studies ${ }^{12}$ reported separately the outcomes for

Table 1 Characteristics of included trials

\begin{tabular}{|c|c|c|c|c|c|c|c|c|c|c|c|}
\hline Study & Year & Study design & $\begin{array}{l}\text { Treatment } \\
\text { groups }\end{array}$ & $\begin{array}{l}\text { No of } \\
\text { patients }\end{array}$ & $\begin{array}{l}\text { Age } \\
\text { (years) }\end{array}$ & $\begin{array}{l}\text { LDL- } \\
\text { cholesterol } \\
\text { (mg/dl) }\end{array}$ & Diabetes & $\begin{array}{l}\text { Aortic jet } \\
\text { velocity } \\
\text { (m/sec) }\end{array}$ & $\begin{array}{l}\text { Aortic } \\
\text { valve area } \\
\left(\mathrm{cm}^{2}\right)\end{array}$ & $\begin{array}{l}\text { Transaortic } \\
\text { pressure } \\
\text { gradient } \\
(\mathrm{mm} \mathrm{Hg})\end{array}$ & Follow-up \\
\hline \multirow{2}{*}{ 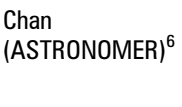 } & \multirow[t]{2}{*}{2010} & \multirow{2}{*}{$\begin{array}{l}\text { Prospective } \\
\text { randomised }\end{array}$} & Placebo & 135 & $58 \pm 14$ & $122 \pm 29$ & NA & $3.19 \pm 0.42$ & $1.56 \pm 0.70$ & Mean $23 \pm 8$ & \multirow{2}{*}{$\begin{array}{l}\text { Median } 3.5 \\
(2.1-4.5) \text { years }\end{array}$} \\
\hline & & & $\begin{array}{l}\text { Rosuvastatin } \\
40 \mathrm{mg} / \text { day }\end{array}$ & 134 & $58 \pm 13$ & $124 \pm 25$ & NA & $3.16 \pm 0.42$ & $1.49 \pm 0.71$ & Mean $23 \pm 8$ & \\
\hline \multirow{2}{*}{$\begin{array}{l}\text { Cowell } \\
\text { (SALTIRE) }^{4}\end{array}$} & \multirow[t]{2}{*}{2005} & \multirow{2}{*}{$\begin{array}{l}\text { Prospective } \\
\text { randomised }\end{array}$} & Placebo & 78 & $68 \pm 10$ & $133 \pm 30$ & $4(5 \%)$ & $3.45 \pm 0.67$ & $1.02 \pm 0.41$ & Peak $50 \pm 20$ & \multirow{2}{*}{$\begin{array}{l}\text { Median } 25 \\
(7-36) \text { months }\end{array}$} \\
\hline & & & $\begin{array}{l}\text { Atorvastatin } \\
80 \mathrm{mg} / \text { day }\end{array}$ & 77 & $68 \pm 10$ & $137 \pm 34$ & $3(4 \%)$ & $3.39 \pm 0.62$ & $1.03 \pm 0.40$ & Peak $48 \pm 17$ & \\
\hline \multirow[t]{2}{*}{ Mohler ${ }^{10}$} & \multirow[t]{2}{*}{2007} & \multirow{2}{*}{$\begin{array}{l}\text { Prospective } \\
\text { observational }\end{array}$} & No statins & 22 & $64 \pm 10$ & $110 \pm 33$ & $3(14 \%)$ & NA & $1.22 \pm 0.25$ & NA & \multirow[t]{2}{*}{12 months } \\
\hline & & & Statins & 31 & $70 \pm 10$ & & $7(18 \%)$ & NA & $1.13 \pm 0.27$ & NA & \\
\hline \multirow{2}{*}{$\begin{array}{l}\text { Moura } \\
\text { (RAAVE) }^{11}\end{array}$} & \multirow[t]{2}{*}{2007} & \multirow{2}{*}{$\begin{array}{l}\text { Prospective } \\
\text { open label }\end{array}$} & No treatment & 60 & $74 \pm 9$ & $117 \pm 21$ & $13(22 \%)$ & $3.62 \pm 0.61$ & $1.20 \pm 0.35$ & Mean $36 \pm 13$ & \multirow{2}{*}{$\begin{array}{l}\text { Mean } 73 \pm 24 \\
\text { weeks }\end{array}$} \\
\hline & & & $\begin{array}{l}\text { Rosuvastatin } \\
20 \mathrm{mg} / \text { day }\end{array}$ & 61 & $73 \pm 9$ & $158 \pm 32$ & $26(43 \%)$ & $3.65 \pm 0.64$ & $1.23 \pm 0.43$ & Mean $35 \pm 13$ & \\
\hline \multirow{2}{*}{$\begin{array}{l}\text { Rossebo } \\
\text { (SEAS) }^{5}\end{array}$} & \multirow[t]{2}{*}{2008} & \multirow{2}{*}{$\begin{array}{l}\text { Prospective } \\
\text { randomised }\end{array}$} & Placebo & 929 & $67 \pm 10$ & $139 \pm 35$ & NA & $3.10 \pm 0.54$ & $1.27 \pm 0.46$ & Mean 23.0 \pm 8.7 & \multirow{2}{*}{$\begin{array}{l}\text { Median } 52.2 \\
\text { months }\end{array}$} \\
\hline & & & $\begin{array}{l}\text { Simvastatin } \\
\text { (40-80 mg/day) } \\
\text { plus ezetimibe }\end{array}$ & 944 & $68 \pm 9$ & $140 \pm 36$ & NA & $3.09 \pm 0.55$ & $1.29 \pm 0.48$ & Mean $22.7 \pm 8.8$ & \\
\hline \multirow[t]{4}{*}{$\begin{array}{l}\text { Antonini- } \\
\text { Canterin }^{12}\end{array}$} & \multirow[t]{4}{*}{2008} & \multirow[t]{4}{*}{ Retrospective } & $\begin{array}{l}\text { No statins mild } \\
\text { aortic stenosis }\end{array}$ & 360 & $71 \pm 8$ & NA & $82(23 \%)$ & $2.3 \pm 0.2$ & NA & Mean $13.1 \pm 3.2$ & \multirow[t]{4}{*}{$\begin{array}{l}\text { Mean } 5.6 \pm 3.2 \\
\text { years }\end{array}$} \\
\hline & & & $\begin{array}{l}\text { Statins mild } \\
\text { aortic stenosis }\end{array}$ & 141 & $71 \pm 7$ & NA & $50(36 \%)$ & $2.3 \pm 0.2$ & NA & Mean $12.7 \pm 3.1$ & \\
\hline & & & $\begin{array}{l}\text { No statins } \\
\text { moderate aortic } \\
\text { stenosis }\end{array}$ & 214 & $72 \pm 8$ & NA & $42(20 \%)$ & $3.3 \pm 0.2$ & NA & Mean $26.1 \pm 5.1$ & \\
\hline & & & $\begin{array}{l}\text { Statins moderate } \\
\text { aortic stenosis }\end{array}$ & 62 & $70 \pm 8$ & NA & $14(23 \%)$ & $3.3 \pm 0.2$ & NA & Mean $26.0 \pm 5.0$ & \\
\hline \multirow[t]{2}{*}{ Bellamy $^{13}$} & \multirow[t]{2}{*}{2002} & \multirow[t]{2}{*}{ Retrospective } & No statins & 118 & $78 \pm 12$ & $137 \pm 43$ & $28(24 \%)$ & $3.0 \pm 0.8$ & $1.20 \pm 0.35$ & Mean $22 \pm 12$ & \multirow{2}{*}{$\begin{array}{l}\text { Mean } 3.7 \pm 2.3 \\
\text { years }\end{array}$} \\
\hline & & & Statins & 38 & $73 \pm 11$ & $164 \pm 49$ & $9(24 \%)$ & $2.8 \pm 0.5$ & $1.32 \pm 0.29$ & Mean 18 \pm 7 & \\
\hline \multirow[t]{2}{*}{ Kuwabara $^{14}$} & \multirow[t]{2}{*}{2006} & \multirow[t]{2}{*}{ Retrospective } & No statins & 20 & $75 \pm 5$ & NA & $3(15 \%)$ & \multirow[t]{2}{*}{$3.1 \pm 1.0$} & NA & Mean $42 \pm 29$ & $31 \pm 23$ months \\
\hline & & & Statins & 13 & $74 \pm 5$ & NA & $6(46 \%)$ & & NA & & $30 \pm 20$ months \\
\hline Novaro $^{15}$ & 2001 & Retrospective & No statins & 117 & $67 \pm 13$ & $131(112-143)$ & $23(20 \%)$ & NA & $1.2(1.0-1.4)$ & Mean $15(12-22)$ & Mean 21 months \\
\hline & & & Statins & 57 & $71 \pm 9$ & $128(94-146)$ & $20(35 \%)$ & NA & $1.2(1.0-1.4)$ & Mean $15(12-22)$ & \\
\hline Rosenhek $^{16}$ & 2004 & Retrospective & No statins & 161 & $69 \pm 11$ & $141 \pm 39$ & $32(20 \%)$ & $3.92 \pm 0.86$ & $0.84 \pm 0.23$ & Mean $42 \pm 20$ & Median $24 \pm 18$ \\
\hline & & & Statins & 50 & $72 \pm 8$ & $145 \pm 38$ & $11(22 \%)$ & $4.08 \pm 0.86$ & $0.82 \pm 0.23$ & Mean $42 \pm 18$ & months \\
\hline
\end{tabular}




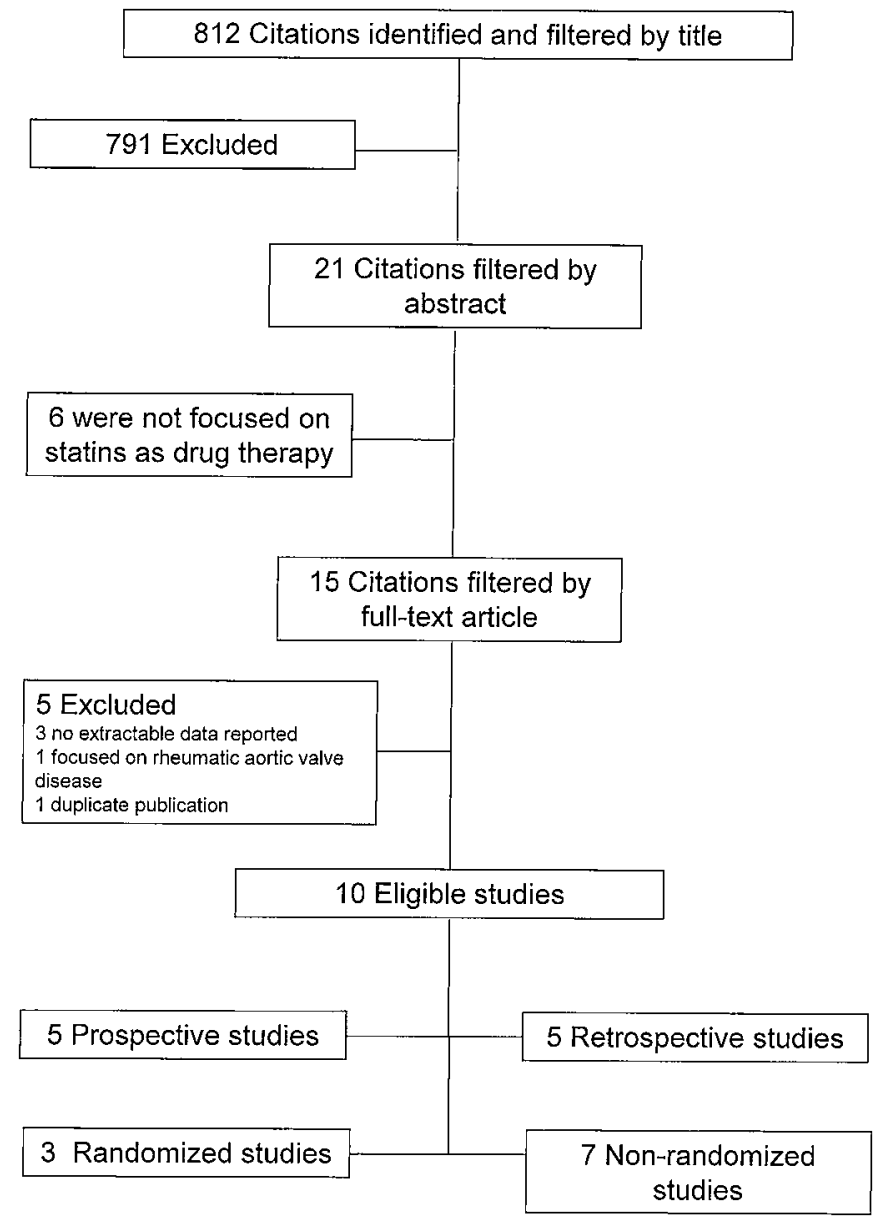

Figure 1 Flow chart of the meta-analysis.

Figure 2 Meta-analysis of studies (denoted by first author and publication year) assessing the effect of statin treatment on death from any cause at follow-up (A, OR and $95 \% \mathrm{Cl})$, death from cardiovascular causes at follow-up ( $B, 0 R$ and $95 \% \mathrm{Cl}$ ), and need to undergo aortic valve surgery at follow-up (C, OR and $95 \% \mathrm{CI}$ ).

Squares indicating individual trial differences are scaled according to weighting in the metaanalysis. The width of the diamond for pooled data denotes the lower and upper $95 \% \mathrm{Cl}$. Note that the $\mathrm{x}$-axis is logarithmic. patients affected by mild aortic stenosis and moderate aortic stenosis, and for that reason data concerning these subcategories of patients were inserted separately into the meta-analysis.

In the end, a total of 3822 participants (2214 non-statintreated and 1608 statin-treated) in 10 studies provided data for this meta-analysis (see figure 1).

\section{Meta-analysis}

Figures 2-4 report the forrest plots of the meta-analyses on the endpoints of interest analysed based on prospective and retrospective study design, whereas supplementary data report the forrest plots of the studies categorised based on randomised and non-randomised study design (see supplementary figure 1, panels A-G, available online only).

As to outcomes, there were no differences between statintreated and untreated patients. All-cause mortality (OR 0.98; $95 \%$ CI 0.74 to 1.30; figure $2 \mathrm{~A}$ ), cardiovascular mortality (OR 0.79 ; $95 \%$ CI 0.54 to 1.15 ; figure $2 \mathrm{~B}$ ), and the need for aortic valve surgery (OR $0.92 ; 95 \%$ CI 0.76 to 1.10 ; figure $2 \mathrm{C}$ ) were not statistically significantly reduced. Notably, data concerning hard outcomes were available only in prospective but not in retrospective trials.

Concerning the progression of aortic valve stenosis over time (tables 2 and 3), the analysis of the variables (jet velocity progression, mean annual decrease in aortic valve area, peak and mean aortic gradient progression) that were considered gave consistent results, showing that a possible protective effect of statins is supported only by low-quality studies (retrospective or non-randomised), but not by high-quality studies (prospective and randomised)

In fact, although the overall effect of statin treatment on the mean annual difference of jet velocity progression $(-0.08 \mathrm{~m} / \mathrm{s}$ per year, $95 \% \mathrm{CI}-0.13$ to $-0.03, p=0.0007$; figure $3 \mathrm{~A}$ ) and the mean annual difference in aortic valve area $\left(-0.02 \mathrm{~cm}^{2} /\right.$ year,

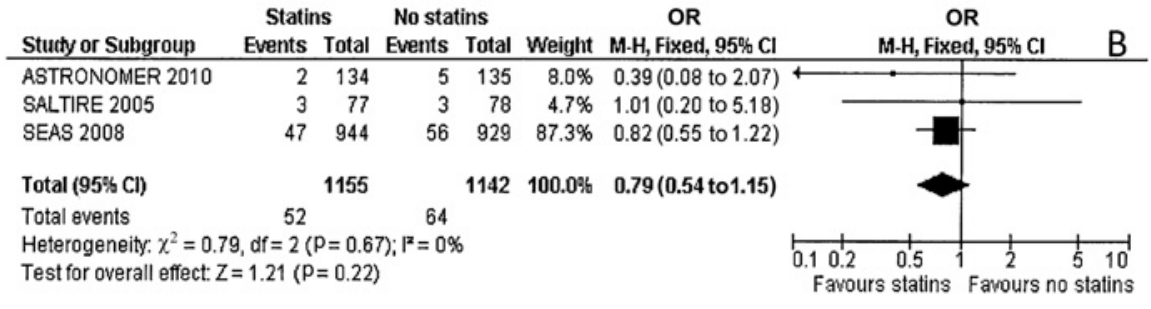

\begin{tabular}{|c|c|c|c|c|c|c|c|c|c|}
\hline Stucty or Subgroup & $\begin{array}{l}\text { Statir } \\
\text { Events }\end{array}$ & Total & No statins & Total & \multicolumn{2}{|c|}{$\begin{array}{c}\text { OR } \\
\text { Weight } \quad \text { M-H, Fixed, 95\% Cl }\end{array}$} & & $\begin{array}{c}\text { OR } \\
\text { M-H, Fixed, 95\% Cl }\end{array}$ & C \\
\hline ASTRONOMER 2010 & 28 & 134 & 27 & 135 & $8.8 \%$ & $1.06(0.58$ to 1.91$)$ & & & \\
\hline RAAVE 2007 & 5 & 61 & 3 & 60 & $1.2 \%$ & $1.70(0.39$ to 7.44$)$ & & & \\
\hline SALTIRE 2005 & 11 & 77 & 19 & 78 & $6.7 \%$ & $0.52(0.23$ to 1.18$)$ & & & \\
\hline SEAS 2008 & 267 & 944 & 278 & 929 & $83.3 \%$ & $0.92(0.76$ to 1.13$)$ & & & \\
\hline Total $(95 \% \mathrm{Cl})$ & & 1216 & & 1202 & $100.0 \%$ & $0.92(0.76$ to 1.10$)$ & & & \\
\hline Total events & 311 & & 327 & & & & & & \\
\hline $\begin{array}{l}\text { Heterogeneity: } \chi^{2}=2.7 \\
\text { Test for overall effect: }\end{array}$ & $\begin{array}{l}5, d f=3(p \\
=0.93\langle p\end{array}$ & $\begin{array}{l}P=0.43 \\
=0.35)\end{array}$ & 3); $; 1^{2}=09$ & & & & $\begin{array}{l}0.10 .2 \\
\text { Favour }\end{array}$ & $\begin{array}{cc}0.5 & 1 \\
\text { rs statins } & 2 \\
\text { Favours n }\end{array}$ & $\begin{array}{ll}5 & 10 \\
\text { statin }\end{array}$ \\
\hline
\end{tabular}


Figure 3 Meta-analysis of studies (denoted by first author and publication year) assessing the effect of statin treatment on peak aortic jet velocity progression $(A$, mean difference and $95 \% \mathrm{Cl}$ ) and aortic valve area decrease (B, mean difference and $95 \% \mathrm{Cl}$ ). Squares indicating individual trial differences are scaled according to weighting in the meta-analysis. The width of the diamond for pooled data denotes the lower and upper $95 \% \mathrm{Cl}$.

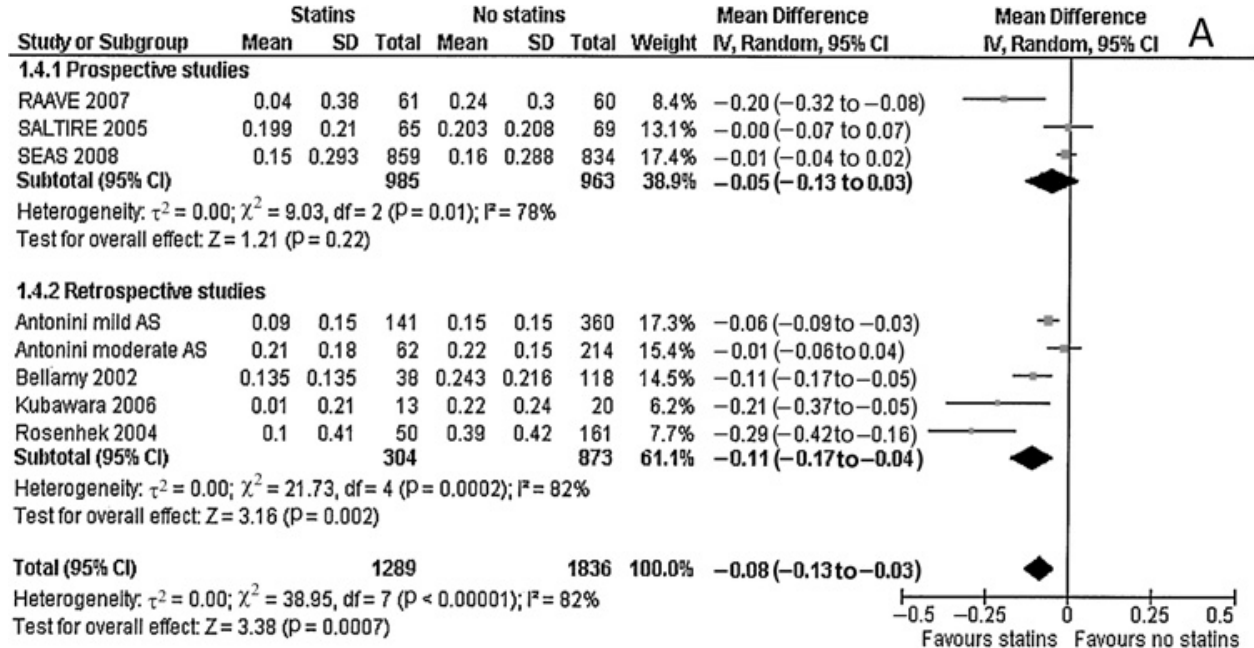

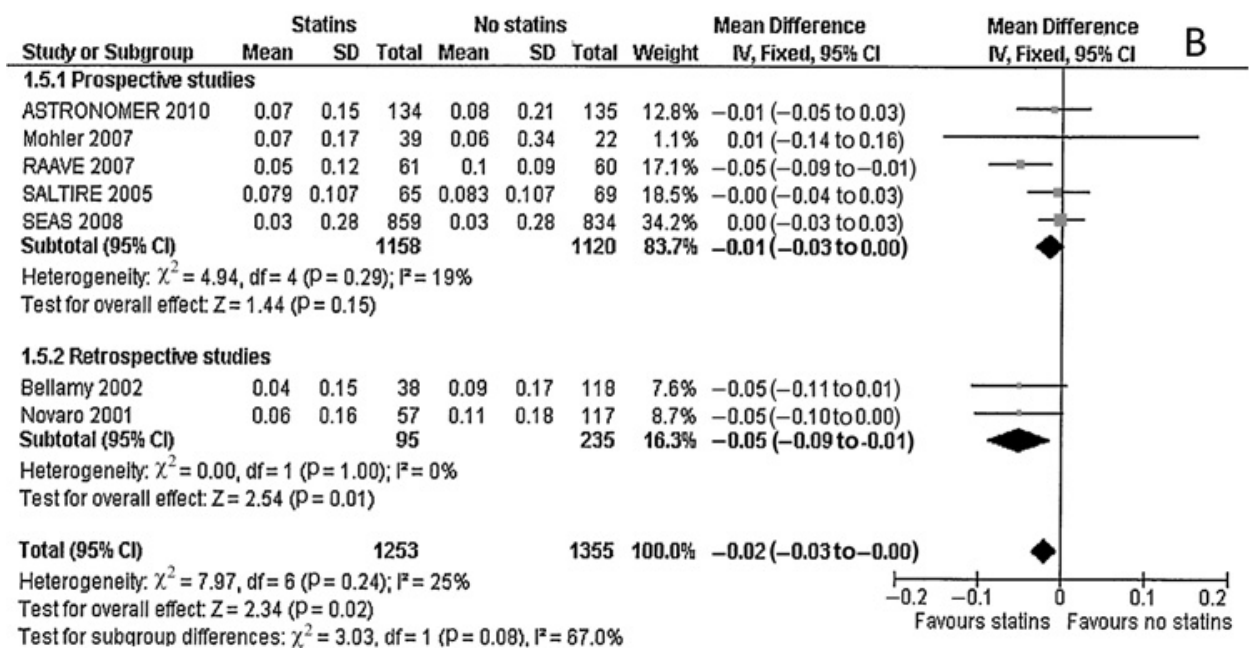

$95 \%$ CI -0.03 to $0.00, p=0.02$; figure $3 \mathrm{~B}$ ) was statistically significant, the subanalyses based on the quality of studies showed that the effect was driven only by lower-quality studies, whereas in higher-quality studies there was no effect. The progression of peak aortic gradient $(-1.76 \mathrm{~mm} \mathrm{Hg} /$ year, $95 \% \mathrm{CI}$ -3.73 to $0.21, \mathrm{p}=0.08$; figure $4 \mathrm{~A})$ and mean aortic gradient $(-0.99 \mathrm{~mm} \mathrm{Hg} /$ year, 95\% CI $-2.04,0.07, \mathrm{p}=0.07$; figure 4B) was slightly lower in statin-treated patients, but this did not reach statistical significance; also in this case the discrepancy in statin effect between high and low-quality studies was evident, only lower-quality studies being in favour of statin treatment.

Finally, there was heterogeneity in the analyses concerning the progression of jet velocity, of peak and mean aortic gradient; and the inspection of funnel plots in these cases showed asymmetry suggesting publication bias (the funnel plots are available from the author upon request) with a significant Egger's test (tables 2 and 3).

Concerning the analysis of statins' effect on aortic stenosis progression parameters in studies that enrolled patients with average low-density lipoprotein cholesterol levels of $130 \mathrm{mg} / \mathrm{dl}$ or less, only three out of 10 studies were available for final analysis, and data were available for aortic valve area decrease over time and for peak and mean aortic gradient progression, but not for jet velocity progression. Statin treatment did not affect these parameters (please see supplementary figure $2 \mathrm{~A}-\mathrm{C}$, available online only), but the limits due to a small sample size should be considered.
Finally, meta-regression analyses did not support a role of statin treatment duration in aortic stenosis progression (please see supplementary figures 3 and 4 as an example, available online only).

\section{DISCUSSION}

Non-rheumatic calcific aortic stenosis is the leading valve disease in western countries and is closely related to ageing. Less invasive techniques for valve replacement (ie, transcatheter aortic valve implantation) have recently been introduced in clinical practice, ${ }^{17}$ and these techniques will allow further growth in aortic valve surgical procedures in a wider population of older patients. This will, however, cause an increase in health expenditure for this disease that now is estimated to be approximately US\$1 billion per year in the USA. ${ }^{18}$ The possibility of reducing the progression of this disease with drug therapy is thus consequently of great interest for all health organisations.

The assumption that calcific aortic stenosis is only a passive, age-related disease has been strongly questioned by numerous studies showing that this disease has several biological pathways in common with atherosclerosis, ${ }^{3}$ which is why investigators have assessed the effect of statins in this type of patient.

Statins reduce the occurrence of ischaemic cardiovascular events not only in secondary prevention but also in high-risk otherwise healthy patients who are candidates for primary prevention. ${ }^{19}$ In addition, evidence from the JUPITER trial suggests that statin treatment in patients with normal 
Figure 4 Meta-analysis of studies (denoted by first author and publication year) assessing the effect of statin treatment on peak aortic gradient progression ( $A$, mean difference and $95 \% \mathrm{Cl}$ ), and on mean aortic gradient progression $(B$, mean difference and $95 \% \mathrm{CI}$ ). Squares indicating individual trial differences are scaled according to weighting in the meta-analysis. The width of the diamond for pooled data denotes the lower and upper $95 \% \mathrm{Cl}$.

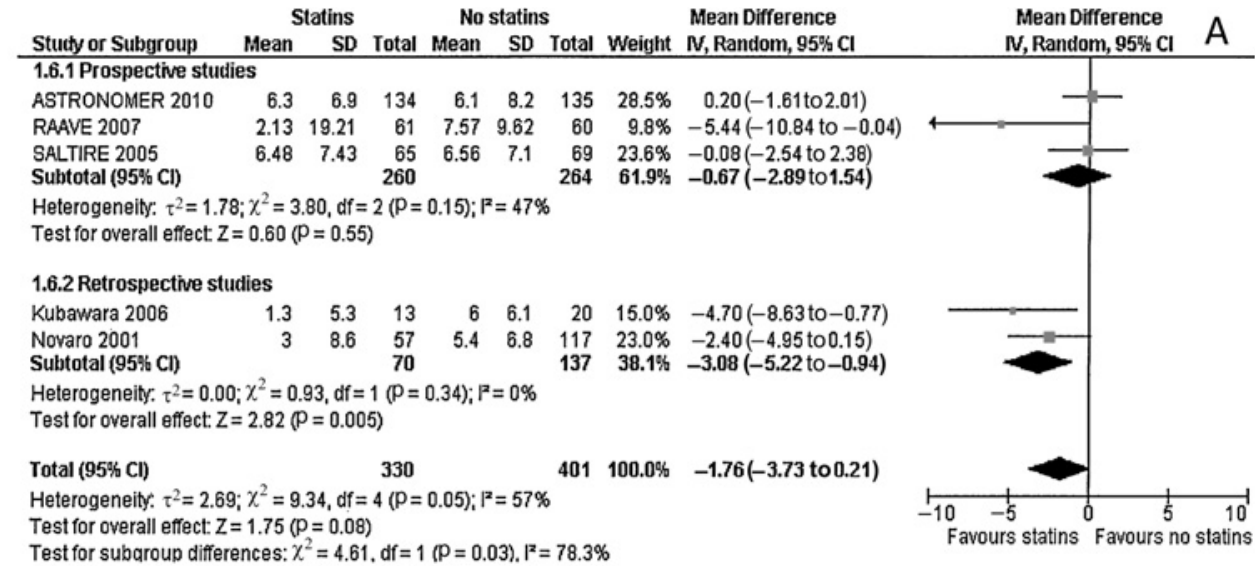

\begin{tabular}{|c|c|c|c|c|c|c|c|c|c|c|c|}
\hline \multirow[b]{2}{*}{ Stucty or Subgroup } & \multicolumn{3}{|c|}{ Statins } & \multicolumn{3}{|c|}{ No statins } & \multirow{3}{*}{\multicolumn{2}{|c|}{$\begin{array}{c}\text { Mean Difference } \\
\text { Weight } \mathrm{N} \text {, Random, 95\% CI } \\
\end{array}$}} & & \multirow{2}{*}{$\begin{array}{c}\text { Mean Difference } \\
\text { N, Random, } 95 \% \mathrm{Cl}\end{array}$} & \multirow{2}{*}{ B } \\
\hline & Mean & SD & Total & Mean & SD & Total & & & & & \\
\hline \multicolumn{10}{|c|}{ 1.7.1 Prospective studies } & & \\
\hline ASTRONOMER 2010 & 3.8 & 4.4 & 134 & 3.9 & 4.9 & 135 & $24.3 \%$ & $-0.10(-1.21$ to1.01) & & & \\
\hline RAAVE 2007 & 2.08 & 8.15 & 61 & 5.06 & 7.17 & 60 & $10.3 \%$ & $-2.98(-5.71$ to -0.25$)$ & & & \\
\hline $\begin{array}{l}\text { SEAS } 2008 \\
\text { Subtotal }(95 \% \mathrm{Cl})\end{array}$ & 2.7 & 2.9 & $\begin{array}{r}859 \\
1054\end{array}$ & 2.8 & 2.8 & $\begin{array}{r}834 \\
1029\end{array}$ & $\begin{array}{l}32.5 \% \\
67.1 \%\end{array}$ & $\begin{array}{l}-0.10(-0.37 \text { to } 0.17) \\
-0.36(-1.25 \text { to } 0.53)\end{array}$ & & & \\
\hline \multicolumn{12}{|c|}{$\begin{array}{l}\text { Heterogeneilty: } \tau^{2}=0.33 ; \chi^{2}=4.22, d f=2(P=0.12) ; 1^{2}=53 \% \\
\text { Test for overall effect: } Z=0.79(P=0.43)\end{array}$} \\
\hline \multicolumn{12}{|c|}{ 1.7.2 Retrospective studies } \\
\hline Bellamy 2002 & 2.9 & 3.4 & 38 & 5.5 & 6.4 & 118 & $19.1 \%$ & $-2.60(-4.18$ to -1.02$)$ & & - & \\
\hline $\begin{array}{l}\text { Novaro } 2001 \\
\text { Subtotal }(95 \% \mathrm{Cl})\end{array}$ & 2.4 & 7.6 & $\begin{array}{l}57 \\
95\end{array}$ & 3.3 & 5.1 & $\begin{array}{l}117 \\
235\end{array}$ & $\begin{array}{l}13.8 \% \\
32.9 \%\end{array}$ & $\begin{array}{l}-0.90(-3.08 \text { to } 1.28) \\
-1.92(-3.55 \text { to }-0.29)\end{array}$ & & & \\
\hline \multicolumn{12}{|c|}{$\begin{array}{l}\text { Heterogeneity: } \tau^{2}=0.50 ; \chi^{2}=1.53, d f=1(P=0.22) ; F^{2}=35 \% \\
\text { Test for overall effect: } Z=2.31(P=0.02)\end{array}$} \\
\hline Total $(95 \% \mathrm{Cl})$ & & & 1149 & & & 1264 & $100.0 \%$ & $-0.99(-2.04$ to 0.07$)$ & & & \\
\hline \multicolumn{9}{|c|}{$\begin{array}{l}\text { Heterogeneily: } \tau^{2}=0.88 ; \chi^{2}=13.76, d f=4(P=0.008) ; P=71 \% \\
\text { Test for overall effect: } Z=1.82(P=0.07) \\
\text { Test for subaroup differences: } \chi^{2}=8.01, d f=1(P=0.005), I^{2}=87.5 \%\end{array}$} & $\stackrel{\vdash}{-10}$ & $\begin{array}{llr}-5 & 0 & 5 \\
\text { durs statins } & \text { Favours } n\end{array}$ & $\stackrel{10}{\overrightarrow{10}}$ \\
\hline
\end{tabular}

cholesterol levels but elevated C-reactive protein reduces the risk of cardiovascular disease mortality and morbidity by almost half, ${ }^{20}$ showing that, besides their cholesterol-lowering effects, statins possess pronounced anti-inflammatory and anticoagulant effects. ${ }^{21} 22$ Statins might therefore modulate the progression of non-rheumatic calcific aortic stenosis in three ways: by reducing cholesterol levels, a well-known risk factor for aortic stenosis; ${ }^{3}$ by attenuating the inflammatory burst within valve tissue; ${ }^{3}$ and by modulating systemic ${ }^{3}$ and local $^{23}$ haemostatic changes involved in the course of the disease.

Table 2 Clinical outcomes by prospective and retrospective studies

\begin{tabular}{|c|c|c|c|c|c|c|c|c|c|c|c|}
\hline \multirow[b]{2}{*}{ Hard outcomes } & \multirow[b]{2}{*}{$\mathbf{n}(\mathbf{N})$} & \multicolumn{2}{|l|}{ Events } & \multirow{2}{*}{\multicolumn{2}{|c|}{ OR $(95 \% \mathrm{Cl})$}} & \multirow{2}{*}{\multicolumn{2}{|c|}{$\begin{array}{l}\text { p For overall } \\
\text { effect }\end{array}$}} & \multicolumn{3}{|l|}{ Heterogeneity } & \multirow{2}{*}{$\begin{array}{l}\text { Egger's test } \\
\text { p value }\end{array}$} \\
\hline & & Statins & No statins & & & & & p Value (0 sta & & $I^{2}$ & \\
\hline $\begin{array}{l}\text { Death from any cause } \\
\text { (only prospective studies available) }\end{array}$ & $2149(3)$ & 109/1082 (10.1\%) & $109 / 1067(10.2 \%)$ & 0.98 & to 1.30$)$ & 0.91 & & 0.33 & & $9 \%$ & 0.15 \\
\hline $\begin{array}{l}\text { Death from cardiovascular causes } \\
\text { (only prospective studies available) }\end{array}$ & $2297(3)$ & $52 / 1155(4.5 \%)$ & $64 / 1142(5.6 \%)$ & 0.79 & to 1.15$)$ & 0.22 & & 0.67 & & $0 \%$ & 0.70 \\
\hline \multirow{2}{*}{$\begin{array}{l}\text { Aortic valve surgery } \\
\text { (only prospective studies available) }\end{array}$} & $2418(4)$ & $311 / 1216(25.6 \%)$ & $327 / 1202$ (27.2\%) & 0.92 & to 1.10$)$ & 0.35 & & 0.43 & & $0 \%$ & 0.99 \\
\hline & & & \multirow{2}{*}{\multicolumn{2}{|c|}{ Mean difference $(95 \% \mathrm{Cl})$}} & \multirow{2}{*}{\multicolumn{2}{|c|}{$\begin{array}{l}\text { p For overall } \\
\text { effect }\end{array}$}} & \multicolumn{4}{|c|}{ Heterogeneity } & \multirow{2}{*}{$\begin{array}{l}\text { Egger's test } \\
\text { p value }\end{array}$} \\
\hline \multicolumn{2}{|l|}{ Aortic valve stenosis progression } & $n(N)$ & & & & & p Val & se (0 statistic) & $\mathbf{I}^{2}$ & & \\
\hline \multicolumn{2}{|l|}{ Jet velocity progression (m/s per year) } & $3125(7)$ & \multicolumn{2}{|c|}{$-0.08(-0.13$ to -0.03$)$} & \multicolumn{2}{|l|}{0.0007} & \multicolumn{2}{|c|}{$<0.00001$} & \multicolumn{2}{|c|}{$82 \%$} & 0.02 \\
\hline \multicolumn{2}{|l|}{ Prospective studies } & $1948(3)$ & \multicolumn{2}{|c|}{$-0.05(-0.13$ to 0.03$)$} & \multicolumn{2}{|l|}{0.22} & \multicolumn{2}{|c|}{0.01} & \multicolumn{2}{|c|}{$78 \%$} & \\
\hline \multicolumn{2}{|l|}{ Retrospective studies } & $1177(4)$ & \multicolumn{2}{|c|}{$-0.11(-0.17$ to -0.04$)$} & \multicolumn{2}{|l|}{0.002} & \multicolumn{2}{|c|}{0.0002} & \multicolumn{2}{|c|}{$82 \%$} & \\
\hline \multicolumn{2}{|l|}{ Aortic valve area decrease (sq $\mathrm{cm} /$ year) } & $2608(7)$ & \multicolumn{2}{|c|}{$-0.02(-0.03$ to 0.00$)$} & \multicolumn{2}{|l|}{0.02} & \multicolumn{2}{|c|}{0.24} & \multicolumn{2}{|c|}{$25 \%$} & 0.21 \\
\hline \multicolumn{2}{|l|}{ Prospective studies } & $2278(5)$ & $-0.01(-0.03$ to 0.0 & & 0.15 & & 0.2 & & $19 \%$ & & \\
\hline Retrospective studies & & $330(2)$ & $-0.05(-0.09$ to -0 & $01)$ & 0.01 & & 1.0 & & $0 \%$ & & \\
\hline Peak aortic gradient progression $(\mathrm{mm}$ & $\mathrm{Hg} /$ year) & $731(5)$ & $-1.76(-3.73$ to 0.2 & & 0.08 & & 0.0 & & $57 \%$ & & 0.03 \\
\hline Prospective studies & & $524(3)$ & $-0.67(-2.89$ to 1.5 & & 0.55 & & 0.15 & & $47 \%$ & & \\
\hline Retrospective studies & & $207(2)$ & $-3.08(-5.22$ to -0 & $.94)$ & 0.005 & & 0.3 & & $0 \%$ & & \\
\hline Mean aortic gradient progression (m & n Hg/year) & $2413(5)$ & $-0.99(-2.04$ to 0.0 & & 0.07 & & 0.0 & & $71 \%$ & & 0.04 \\
\hline Prospective studies & & $2083(3)$ & $-0.36(-1.25$ to 0.5 & & 0.43 & & 0.12 & & $53 \%$ & & \\
\hline Retrospective studies & & $330(2)$ & $-1.92(-3.55$ to -0 & .29) & 0.02 & & 0.2 & & $35 \%$ & & \\
\hline
\end{tabular}

$\mathrm{n}$, number of patients; N, number of trials 
Table 3 Clinical outcomes by randomised and non-randomised studies

\begin{tabular}{|c|c|c|c|c|c|c|c|c|c|c|}
\hline \multirow[b]{2}{*}{ Hard outcomes } & \multirow[b]{2}{*}{$n(N)$} & \multicolumn{2}{|l|}{ Events } & \multirow{2}{*}{\multicolumn{2}{|c|}{ OR (95\% Cl) }} & \multirow{2}{*}{\multicolumn{2}{|c|}{$\begin{array}{l}\text { p For overall } \\
\text { effect }\end{array}$}} & \multicolumn{2}{|l|}{ Heterogeneity } & \multirow{2}{*}{$\begin{array}{l}\text { Egger's test } \\
\text { p value }\end{array}$} \\
\hline & & Statins & No statins & & & & & $\mathrm{p}$ Value (0 sta & $I^{2}$ & \\
\hline Death from any cause & $2149(3)$ & 109/1082 (10.1\%) & $109 / 1067(10.2 \%)$ & \multicolumn{2}{|c|}{$0.98(0.74$ to 1.30$)$} & \multicolumn{2}{|l|}{$\begin{array}{l}0.91 \\
0.92\end{array}$} & 0.33 & $9 \%$ & \multirow[t]{2}{*}{0.15} \\
\hline Non-randomised studies & $121(1)$ & $1 / 61(1.6 \%)$ & $4 / 60(6.7 \%)$ & \multicolumn{2}{|c|}{0.23 (0.03 to 2.15$)$} & \multicolumn{2}{|l|}{0.20} & NA & NA & \\
\hline $\begin{array}{l}\text { Death from cardiovascular causes } \\
\text { (only randomised studies available) }\end{array}$ & $2297(3)$ & $52 / 1155(4.5 \%)$ & $64 / 1142(5.6 \%)$ & \multicolumn{2}{|c|}{$0.79(0.54$ to 1.15$)$} & \multicolumn{2}{|l|}{0.22} & 0.67 & $0 \%$ & 0.70 \\
\hline Aortic valve surgery & $2418(4)$ & $311 / 1216(25.6 \%)$ & $327 / 1202(27.2 \%)$ & \multicolumn{2}{|c|}{$0.92(0.76$ to 1.10$)$} & 0.35 & & 0.43 & $0 \%$ & \multirow[t]{2}{*}{0.99} \\
\hline \multirow[t]{2}{*}{ Non-randomised studies } & $121(1)$ & $5 / 61(8.2 \%)$ & $3 / 60(5.0 \%)$ & 1.70( & to 7.44 ) & 0.48 & & NA & NA & \\
\hline & & & \multirow{2}{*}{\multicolumn{2}{|c|}{ Mean difference $(95 \% \mathrm{Cl})$}} & \multirow{2}{*}{\multicolumn{2}{|c|}{$\begin{array}{l}\text { p For overall } \\
\text { effect }\end{array}$}} & \multicolumn{3}{|c|}{ Heterogeneity } & \multirow{2}{*}{$\begin{array}{l}\text { Egger's test } \\
\text { p value }\end{array}$} \\
\hline \multicolumn{2}{|l|}{ Aortic valve stenosis progression } & $n(N)$ & & & & & p Val & Ie (0 statistic) & $1^{2}$ & \\
\hline \multicolumn{2}{|l|}{ Jet velocity progression $(\mathrm{m} / \mathrm{s}$ per year) } & $3125(7)$ & $-0.08(-0.13$ to - & .03) & 0.0007 & & $<0.0$ & 001 & $82 \%$ & 0.02 \\
\hline Randomised studies & & $1827(2)$ & $-0.01(-0.03$ to 0. & & 0.48 & & 0.8 & & $0 \%$ & \\
\hline Peak aortic gradient progression $(\mathrm{mm}$ & $\mathrm{Hg} /$ year) & $731(5)$ & $-1.76(-3.73$ to 0. & & 0.08 & & 0.0 & & $57 \%$ & 0.03 \\
\hline Randomised studies & & $403(2)$ & $0.10(-1.36$ to 1.56 & & 0.89 & & 0.8 & & $0 \%$ & \\
\hline Non-randomised studies & & $328(3)$ & $-3.40(-5.39$ to - & .41) & 0.0008 & & 0.4 & & $0 \%$ & \\
\hline Mean aortic gradient progression (mr & n Hg/year) & $2413(5)$ & $-0.99(-2.04$ to 0. & & 0.07 & & 0.0 & & $71 \%$ & 0.04 \\
\hline Randomised studies & & $1962(2)$ & $-0.10(-0.36$ to 0 . & & 0.46 & & 1.0 & & $0 \%$ & \\
\hline Non-randomised studies & & $451(3)$ & $-2.19(-3.35$ to - & .03) & 0.0002 & & 0.3 & & $0 \%$ & \\
\hline
\end{tabular}

$\mathrm{n}$, number of patients; $\mathrm{N}$, number of trials.

Studies investigating the clinical results of statin treatment have given contradictory results. The early enthusiastic findings of observational studies documenting a reduction in the progression of the disorder have been seriously questioned by later, randomised studies, which showed substantial equivalence between statin and placebo-treated patients.

The meta-analysis reported here shows that, on the basis of data published to date, statin treatment does not affect the occurrence, at a mid-term follow-up (average 4 years) of major events in patients affected by calcific non-rheumatic aortic stenosis, and might reduce the rate of aortic stenosis progression over time. Current evidence is not sufficient to warrant statin use in these patients, as it comes only from retrospective, nonrandomised studies, whereas prospective and randomised studies do not show any protective effects of statins on aortic stenosis progression.

Therefore, although statins have well-established effects on major endpoints in several patient populations, both in primary and secondary prevention, they do not have the same effect on major endpoints in patients with calcific aortic stenosis. In fact, our meta-analysis of current evidence shows that statins do not reduce total mortality, cardiovascular mortality or the need for valve surgery after $24-48$ months of treatment in this cohort of patients. However, the number of patients that could be pooled in this analysis was rather small, and multicentre, prospective, randomised studies are needed to clarify the issue definitively. We estimate that a sample size of 6220 and of 11150 patients for each treatment arm would be needed to demonstrate statistically significant differences between treatments in cardiovascular mortality and the need for aortic valve surgery, respectively, at mid-term (mean 39 months) follow-up ( $\alpha=0.05$, power 0.80).

In the patients in our meta-analysis, the effect of statin treatment on hard outcomes was distinctly inferior to that obtained in the JUPITER trial, in which the incidence of major outcomes was halved by statin therapy in patients with normal cholesterol but with elevated inflammatory markers. We hypothesise that statins are most effective during the early stages of stenosis, when inflammation is most active, whereas in the patients we studied the degree of stenosis was far more advanced, as shown by an average jet velocity in all studies greater than $3 \mathrm{~m} / \mathrm{s}$ and by an average aortic valve area of between 1 and $1.4 \mathrm{~cm}^{2}$ (table 1). This hypothesis is also supported by a recent post-hoc analysis of SEAS trial data documenting that in patients affected by calcific aortic stenosis the protection provided by statin treatment is greater in patients with a milder degree of aortic stenosis. ${ }^{24}$

Against the hypothesis of inflammation contributing to aortic stenosis progression is the finding that $\mathrm{C}$-reactive protein has been localised in valve tissue of calcific aortic stenosis and that statin-treated patients show lower valve levels of this marker. ${ }^{25}$ However, there is some doubt as to whether there is an association between C-reactive protein and disease progression. ${ }^{26} 27$

Our meta-analysis also shows that statin treatment might play, if any, a little role in reducing the progression of aortic stenosis over time, with an annual estimated reduction of $0.08 \mathrm{~m} / \mathrm{s}$ per year for peak jet velocity, and an annual reduction of $0.02 \mathrm{~cm}^{2} /$ year for aortic valve area decrease. Otto et al 28 showed that, in asymptomatic patients affected by calcific aortic stenosis (average valve area of $1.3 \mathrm{~cm}^{2}$ and average aortic jet velocity of $3.6 \mathrm{~m} / \mathrm{s}$ ), the approximate annual increase in jet velocity is $0.3 \mathrm{~m} / \mathrm{s}$, with a corresponding decrease of approximately $0.1 \mathrm{~cm}^{2}$ in valve area. Based on these data, statin treatment in the patient population of our meta-analysis might reduce aortic stenosis progression by an estimated $20-25 \%$. This finding, however, is not confirmed by the behaviour of peak and mean aortic gradient; the progression of both these variables was slightly affected by statins, but this was not statistically significant.

In addition, the subanalyses performed on data coming from prospective versus retrospective studies, and from randomised versus non-randomised trials, constantly showed that, for all the 
four variables representing aortic stenosis progression, the effect of statin treatment was evident only in the studies of lower quality (retrospective and non-randomised), whereas no effect was demonstrated in high-quality studies (prospective or randomised).

We conclude that a beneficial effect of statins on disease progression is supported only by observational studies, with all their inherent flaws, and this is not sufficient to support statin use in patients affected by moderate or by higher grades of nonrheumatic calcific aortic stenosis. Future randomised studies will need to address three deficiencies in those currently available: (1) lack of statistical power in detecting any reduction in cardiovascular mortality; (2) too short follow-up periods, given that the disease process takes many decades and only approximately $9 \%$ of patients in patients aged $65-75$ years with aortic sclerosis progress to aortic stenosis in 5 years; ${ }^{29}$ and (3) insufficient discrimination in the selection of patients most likely to benefit from preventive statin therapy. It has previously been hypothesised that, in studies conducted up to now, statin therapy was initiated much too late in the course of disease, and that statin therapy should be initiated at an earlier stage of the disease to be effective. ${ }^{2}{ }^{3}$ Actually, there are insufficient data to support or confute this hypothesis, although this meta-analysis shows that, in patients enrolled at a relatively advanced stage of the disease, statins are not effective in the prevention of cardiovascular events or in the reduction of disease progression. The efficacy of statin therapy needs to be tested in earlier stages of the disease when the transvalvular gradient has not yet ensued, as already suggested by Wierzbicki and colleagues, ${ }^{30}$ and by a study included in our meta-analysis ${ }^{12}$ showing that statins effectively delayed the progression of aortic stenosis in patients with aortic sclerosis and mild aortic stenosis, but not in patients with moderate stenosis. In other words, statin therapy as an effective preventive strategy should now be assessed very early in patients at risk of calcific aortic valve disease, and certainly no later than at the first diagnosis of aortic sclerosis or mild stenosis; and periodic screening with transthoracic echocardiography can help in identifying patients at risk.

In addition, it is possible that the discrepancy between the mild or null effects of statin therapy in moderate aortic stenosis, when the disease is already at an advanced stage, and the more evident results that can be achieved by statin treatment in the case of earlier stages of atherosclerotic disease (JUPITER trial) can be dissolved by the hypothesis that the maximal efficacy of these drugs might be achieved when they are given at earlier stages of both diseases, aortic stenosis and atherosclerosis.

In conclusion, our study does not support the concept that statins may reduce the progression rate of calcific non-rheumatic aortic stenosis; it also strongly indicates the need for adequately powered, well-designed prospective randomised controlled studies in patients at earlier disease stages.

Competing interests None.

Provenance and peer review Not commissioned; externally peer reviewed.

\section{REFERENCES}

1. Carabello BA, Paulus WJ. Aortic stenosis. Lancet 2009;373:956-66.

2. Helske S, Otto CM. Lipid lowering in aortic stenosis: still some light at the end of the tunnel? Circulation 2009:119:2653-5.
3. Parolari A, Loardi C, Mussoni L, et al. Nonrheumatic calcific aortic stenosis: an overview from basic science to pharmacological prevention. Eur J Cardiothorac Surg 2009;35:493-504.

4. Cowell SJ, Newby DE, Prescott RJ, et al. A randomized trial of intensive lipid-lowering therapy in calcific aortic stenosis. N Engl J Med 2005;352:2389-97.

5. Rossebo AB, Pedersen TR, Boman $\mathrm{K}$, et al. Intensive lipid lowering with simvastatin and ezetimibe in aortic stenosis. N Engl J Med 2008;359:1343-56.

6. Chan KL, Teo K, Dumesnil JG, et al. Effect of lipid lowering with rosuvastatin on progression of aortic stenosis. Results of the Aortic Stenosis Progression Observation: Measuring Effects of Rosuvastatin (ASTRONOMER) Trial. Circulation 2010;121:306-14.

7. Liberati A, Altman DG, Tetzlaff J, et al. The PRISMA statement for reporting systematic reviews and meta-analyses of studies that evaluate health care interventions: explanation and elaboration. Ann Intern Med 2009;151:W65-94.

8. Stroup DF, Berlin JA, Morton SC, et al. Meta-analysis of observational studies in epidemiology: a proposal for reporting. Meta-analysis of Observational Studies in Epidemiology (MOOSE) group. JAMA 2000;283:2008-12.

9. Higgins JP, Thompson SG, Deeks JJ, et al. Measuring inconsistency in meta-analyses. BMJ 2003;327:557-60.

10. Mohler ER 3rd, Wang $\mathrm{H}$, Medenilla $\mathrm{E}$, et al. Effect of statin treatment on aortic valve and coronary artery calcification. J Heart Valve Dis 2007;16:378-86.

11. Moura LM, Ramos SF, Zamorano JL, et al. Rosuvastatin affecting aortic valve endothelium to slow the progression of aortic stenosis. J Am Coll Cardiol 2007:49:554-61

12. Antonini-Canterin F, Hirsu M, Popescu BA, et al. Stage-related effect of statin treatment on the progression of aortic valve sclerosis and stenosis. Am J Cardiol 2008; 102:738-42.

13. Bellamy MF, Pellikka PA, Klarich KW, et al. Association of cholesterol levels, hydroxymethylglutaryl coenzyme-A reductase inhibitor treatment, and progression of aortic stenosis in the community. J Am Coll Cardiol 2002;40:1723-30.

14. Kuwabara M, Kitaoka H, Okawa M, et al. Treatment with HMG-CoA reductase inhibitors (statins) attenuates the progression of aortic valve stenosis in the elderly. Geriatr Gerontol Int 2006;6:124-8.

15. Novaro GM, Tiong IY, Pearce GL, et al. Effect of hydroxymethylglutaryl coenzyme A reductase inhibitors on the progression of calcific aortic stenosis. Circulation 2001; 104:2205-9.

16. Rosenhek R, Rader F, Loho N, et al. Statins but not angiotensin-converting enzyme inhibitors delay progression of aortic stenosis. Circulation 2004;110:1291-5

17. Webb JG, Altwegg L, Boone $\mathrm{RH}$, et al. Transcatheter aortic valve implantation: impact on clinical and valve-related outcomes. Circulation 2009;119:3009-16.

18. Moura LM, Maganti K, Puthumana JJ, et al. New understanding about calcific aortic stenosis and opportunities for pharmacologic intervention. Curr Opin Cardiol 2007:22:572-7.

19. Brugts JJ, Yetgin T, Hoeks SE, et al. The benefits of statins in people without established cardiovascular disease but with cardiovascular risk factors: meta-analysis of randomised controlled trials. BMJ 2009;338:b2376

20. Ridker PM, Danielson E, Fonseca FA, et al. Rosuvastatin to prevent vascular events in men and women with elevated C-reactive protein. $N$ Engl J Med 2008;359:2195-207.

21. Gelosa $\mathbf{P}$, Cimino $M$, Pignieri $A$, et al. The role of $H M G-C o A$ reductase inhibition in endothelial dysfunction and inflammation. Vasc Health Risk Manag 2007:3:567-77

22. Greenwood J, Mason JC. Statins and the vascular endothelial inflammatory response. Trends Immunol 2007;28:88-98.

23. Marechaux $\mathbf{S}$, Corseaux D, Vincentelli $A$, et al. Identification of tissue factor in experimental aortic valve sclerosis. Cardiovasc Pathol 2009:18:67-76.

24. Holme I, Boman K, Brudi P, et al. Observed and predicted reduction of ischemic cardiovascular events in the simvastatin and ezetimibe in aortic stenosis trial. $\mathrm{Am} \mathrm{J}$ Cardiol 2010;105:1802-8.

25. Skowasch D, Schrempf S, Preusse CJ, et al. Tissue resident $\mathrm{C}$ reactive protein in degenerative aortic valves: correlation with serum $C$ reactive protein concentrations and modification by statins. Heart 2006;92:495-8

26. Jeevanantham V, Singh N, Izuora K, et al. Correlation of high sensitivity C-reactive protein and calcific aortic valve disease. Mavo Clin Proc 2007:82:171-4.

27. Gring CN, Houghtaling P, Novaro GM, et al. Preoperative cholesterol levels do no predict explant for structural valve deterioration in patients undergoing bioprosthetic aortic valve replacement. J Heart Valve Dis 2006:15:261-8.

28. Otto CM, Burwash IG, Legget ME, et al. Prospective study of asymptomatic valvula aortic stenosis. Clinical, echocardiographic, and exercise predictors of outcome. Circulation 1997;95:2262-70.

29. Novaro GM, Katz R, Aviles RJ, et al. Clinical factors, but not C-reactive protein, predict progression of calcific aortic-valve disease: the Cardiovascular Health Study. J Am Coll Cardiol 2007;50:1992-8.

30. Wierzbicki AS, Viljoen A, Chambers JB. Aortic stenosis and lipids: does intervention work? Curr Opin Cardiol 2010:25:379-84. 